\title{
Effects of Land Use Systems on Soil Fertility at Antra Watershed, Chilga District, Northwestern Highlands of Russia
}

\author{
Habtamu Admas Desta \\ Natural Resources Management, College of Dry Land Agriculture, Samara University, Ethiopia
}

Copyright $\bigcirc 2018$ by authors, all rights reserved. Authors agree that this article remains permanently open access under the terms of the Creative Commons Attribution License 4.0 International License

\begin{abstract}
In Antra watershed, land use system has an effect on soil fertility status where cultivated lands suffered in nutrient depletion. This study, therefore, was designed to investigate effects of different land use systems on soil fertility status of Nitisols of Antra watershed. Twenty-seven soil samples were collected depth wise $(0-15,15-30$ and $30-45 \mathrm{~cm})$ from cultivated, forest and grazing lands based on stratification. Data were analyzed using descriptive statistics. Land use systems and soil depth showed variations in soil physicochemical properties. The maximum $\mathrm{pH}$ (5.03), OC (4.6\%), total $\mathrm{N}(0.28 \%)$, available $\mathrm{S}(11.1 \mathrm{ppm})$, CEC $\left(42.2 \mathrm{cmol}_{\mathrm{c}} \mathrm{kg}^{-1}\right)$, soil exchangeable bases $(\mathrm{Ca}(22.2), \mathrm{K}$ $(0.76)$ and $\left.\mathrm{Na}\left(0.58 \quad \mathrm{cmol}_{\mathrm{c}} \mathrm{kg}^{-1}\right)\right)$ and extractable micronutrients (( $\mathrm{Fe}(14.2)$ and $\mathrm{Mn}(24.1 \mathrm{ppm}))$ were observed on the surface layers of forest land while the minimum were recorded in cultivated land although relatively higher available $\mathrm{P}$ (5.5 ppm) was observed on the surface layers of cultivated land. The results revealed that soil fertility is low in cultivated lands than forest and grazing lands. Hence, it is possible to infer that forest lands were rich in plant nutrients while over cultivation depleted it which urges to take important measures for preserving remnant forests and maintaining the fertility status of cultivated soils in the study area.
\end{abstract}

Keywords Cultivated Land, Fertility Status, Forest Land, Grazing Land, Plant Nutrient Depletion

\section{Introduction}

In Sub-Saharan Africa, soil fertility depletion is the fundamental cause for declining per capital food production as crop lands have a negative nutrient balance, with annual losses ranging from $1.5-7.1 \mathrm{t} \mathrm{ha}^{-1}$ of nitrogen $(\mathrm{N})$, phosphorus $(\mathrm{P})$ and potassium $(\mathrm{K})$ mainly due to crop harvest, leaching and low inputs applied to the soils $[1,2]$. In Ethiopian cultivated fields, about 42 ton per hectare ( $\mathrm{t}$ $\mathrm{ha}^{-1}$ ) of fertile top soil has been lost every year [3] together with important plant nutrients mainly due to inadequate soil and water conservation, and high deforestation.

Evaluating soil physicochemical properties is important to understand the potential status of nutrients in soils of different land use systems [4, 5]. Similarly, [3] reported that evaluating the fertility status of a soil is important to know the productivity level of a soil as soil fertility is one of the parameters of soil productivity whereby the productivity of soils in Ethiopian highlands is declining at a rate of $2-3 \%$ annually. To meet the food demands of rapid increasing population, vast tracts of land are being cultivated more intensively and large areas of grass and forestlands are being overgrazed and deforested, respectively. Changes in land use systems and soil management can have a marked effect on soil fertility [6] mainly the conversion of natural ecosystem (forest land) to crop land results in declining soils physical, chemical and biological properties [7]. Research findings from different corners of the world have revealed that prolonged and intensive cultivation has resulted in deteriorating plant nutrients $[8,9,10]$. Deforestation and cultivation of virgin tropical soils often lead to the depletion of N, P, sulfur (S) and other plant nutrients that lead to aluminum $(\mathrm{Al})$, iron $(\mathrm{Fe})$ and manganese $(\mathrm{Mn})$ toxicity which increase soil acidity [11, 12, 13], and reduce important microbial population.

Physical and chemical properties of soils on land under continuous cultivation could vary from other land use systems $[14,15,16]$. Cultivated soils are poor in their fertility status as they have high bulk density $\left(\mathrm{f}_{\mathrm{b}}\right)[17,18]$, low total porosity $(f)$ [19], low $\mathrm{pH}$ [20] and very low organic matter $(\mathrm{OM})$ or organic carbon $(\mathrm{OC})$ contents $[21$, $22,23]$. Cultivation has also altered other soil chemical properties and characterized by low total $\mathrm{N}[24,22,25$, 
20], available $\mathrm{S}[26,27]$, cation exchange capacity (CEC) [28] and exchangeable bases of calcium $(\mathrm{Ca})$, magnesium $(\mathrm{Mg}), \mathrm{K}$ and sodium $(\mathrm{Na})[29,10,30]$ but relatively high in available $\mathrm{P}[31,15,6]$. The survival and wellbeing of the present and future generations in countries with subsistence agriculture like Ethiopia depend on the extent of maintaining soil fertility [15]. So, land must be carefully managed which urges establishment of land use systems for conserving soil fertility in the long term [16].

The factors causing for nutrient depletion in cultivated lands of highland Ethiopia include cultivation on steep and fragile soils, declining use of fallow, limited recycling of dung and crop residues to soils, low application of external sources of plant nutrients, deforestation, overgrazing and torrential rainfall patterns $[32,33,34,35]$.

Antra watershed has become nutrient depleted and less productive due to over cultivation and deforestation associated with soil erosion and leaching which will make the efforts that have been made to increase crop yields difficult. Besides, the degree, extent, causes and measures of soil fertility decline have not received adequate research attention in northwestern highlands of Ethiopia in general [36] and the study area in particular. Investigating soil physical and chemical properties (soil fertility) in different land use systems could assist policy makers, researchers, extension workers and farmers to have baseline information so as to improve soil productivity of acid soils of the study area and elsewhere which have similar agro-ecology. Research on this line is of paramount importance as the results obtained from such studies could also be used for monitoring soil fertility status of different land use systems. Therefore, this study was conducted to assess the effects of different land use systems on soil fertility status at Antra watershed in northwestern highlands of Ethiopia.

\section{Materials and Methods}

\subsection{Description of the Study Area}

The study was conducted at Antra watershed, located in Chilga District of North Gondar Zone in ANRS of Ethiopia. The watershed is situated at about $60 \mathrm{~km}$ west of Gondar city and $760 \mathrm{~km}$ northwest of Addis Ababa (capital of Ethiopia). Geographically, the watershed lies at $12^{\circ} 32^{\prime} 16^{\prime \prime}-12^{\circ} 35^{\prime} 20^{\prime \prime} \mathrm{N}$ latitudes and $37^{\circ} 03$ ' $58^{\prime \prime}-37^{\circ}$ 06 ' 23 ' E longitudes with an area of $62.68 \mathrm{~km}^{2}$ (6280 ha) and elevations ranging from 1910 and 2267 m.a.s.l.

The formation of soil associates with raw parent materials through progressive and regressive processes [37]. Proper understanding of the nature and properties of soils are necessary for judicious, beneficial and optimal use on suitable basis [38]. Geologically, the study area is covered with thick trap series of volcanic rocks with structural complex which was notably active during the build-up of mid-Tertiary flood basalt pile and middle-Tertiary volcanic mountains of Miocene and Pliocene-Quaternary, accompanied locally by predominantly basaltic volcanism. The trap volcanic series consists mainly of weathered and jointed basalt and soils of the study area were developed from parent materials of volcanic origin, predominantly Tertiary basalt [39]. Soils of Antra watershed are Nitisols which are deep, well-drained, red, tropical soils with more than 30\% clay and moderate to strong angular blocky structure. Weathering is relatively advanced but Nitisols are far more productive than most other red tropical soils which are predominantly found in level to hilly land under tropical rain forest or savannah land [40] that liable to high soil erosion and plant nutrient leaching by heavy and torrential rainfall of the area.

Antra watershed is characterized by unimodal rainfall pattern which is dominated by summer season albeit it occurs from May to October. According to weather data recorded at Aykel Meteorological Station $(5 \mathrm{~km}$ from experimental site), the ten-year (2004-2013) total average annual rainfall for the study area was $1237 \mathrm{~mm}$ that erodes top soil and leach down plant nutrients especially in the cultivated fields. Annual mean minimum and maximum temperatures were 13.6 and $23.7{ }^{\circ} \mathrm{C}$, respectively that aggravated the physical, chemical and biological weathering of rocks and soil erosion as well as leaching down of plant nutrients.

The natural vegetation of Antra watershed is very sparse except some trees and grasses on the reserved areas and area closures due to the rapid and ever increasing population that caused high deforestation rate for cultivation, fuel wood consumption, constructional purpose and overgrazing. The trees occurring on slopes, mainly churches, are remnants of once dense evergreen forest that indicated once upon a time the area was covered with forests with low population pressure. Currently, in the study area, afforestation and re-plantation strategy is being implemented which is dominated mainly by eucalyptus trees.

In Antra watershed, cultivated land accounts for about $68.4 \%$ while grazing, settlement and forest together with area closure lands account for about 23.5, 5.3 and $2.8 \%$, respectively [41] which indicated the occurrence of high degree of deforestation and expansion of cultivation associated with high degree of erosion and plant nutrient leaching. In Antra watershed, however, there is no the practice of fallowing due to high population pressures where land is used intensively. The intense and prolonged use of land for cultivation and animal grazing also makes soils more susceptible to erosion and plant nutrient depletion. 


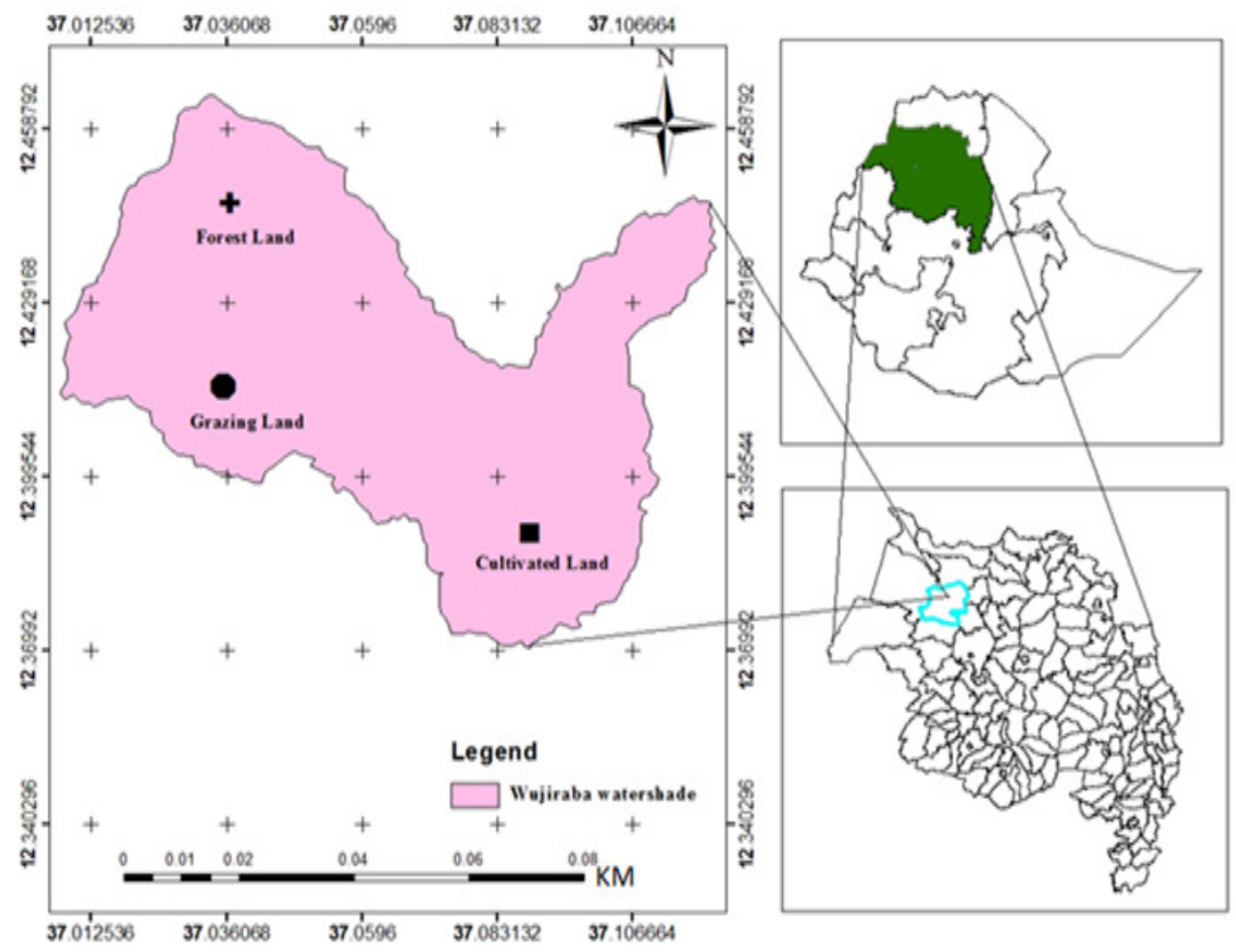

Figure 1. Location map of Wujiraba watershed

\subsection{Land Use Selection and Soil Sampling}

The sampling procedure for selecting representative land use systems was purposive sampling. Three land use systems (cultivated, grazing and forest) were selected and used in this study for assessing soil fertility status on soil groups of Nitisols [40]. Land use sites for soil sample collection were selected using topographic map of the study area based on vegetation, grazing and cultivation history. At the beginning, a general visual field survey was carried out to have a general view of variations in soil physical and morphological characteriscs of the study area because of considerable heterogeneity in soil properties at the spatial scale of a few meters or less. Soil samples were collected from such land use systems using augur. Global positioning system (GPS) and clinometers were used to read the geographical locations and slopes of sampling sites of selected land use systems, respectively.

From cultivated lands, cereal crop land under rain-fed condition was used while from grazing and forest lands, communal grazing land and natural forest land (reserved area) were selected for this study. Representative soil sampling sites were selected randomly from each land use systems according to their slopes. Three representative fields/stratifications were made for each land use systems, and from each stratifications, composite soil samples were collected from $10-15$ soil sub-samples (spots) within three depths of $0-15,15-30$ and $30-45 \mathrm{~cm}$ using auger.

During collection of soil samples; dead plants, furrow, old manures, wet spots, areas near trees and the like were excluded. Composite soil samples which were collected from representative land use systems with three strata were then air-dried and ground for analyzing selected soil physicochemical properties. Separate core soil samples from each sampling depth were taken with a core sampler for analyzing bulk density.

\subsection{Soil Analysis}

Soil physicochemical analysis was carried out at Bahir Dar Soil Testing and Fertility Improvement, and Amhara Design and Supervision Works Agency Soil Laboratory Centers using standard laboratory procedures. Soil texture was determined using hydrometer [42]. Bulk density was determined from undisturbed soil samples using core sampler [43] while particle density $\left(\hat{p}_{\mathrm{s}}\right)$ was measured using psychnometer [44]. Total porosity $(f)$ was calculated from the values of $\hat{p}_{b}$ and $\hat{p}_{\mathrm{s}}$ as:

$$
f=\left(1-\frac{\mathrm{pb}}{\mathrm{ps}}\right) 100
$$

Soil $\mathrm{pH}$ was measured in a suspension of $1: 2.5$ soils to potassium chloride $(\mathrm{KCl})$ solution ratio [45] using a $\mathrm{pH}$ meter. Total $\mathrm{N}$ was determined by micro-Kjedahl method [46] while available $\mathrm{P}$ by extraction with Bray II method [47] using $0.03 \mathrm{M} \mathrm{NH}_{4} \mathrm{~F}$ and $0.1 \mathrm{M} \mathrm{HCl}$ solution. Soil $\mathrm{CEC}$ and exchangeable $\mathrm{Ca}, \mathrm{Mg}, \mathrm{K}$ and $\mathrm{Na}$ were extracted with $1 \mathrm{M} \mathrm{NH}_{4} \mathrm{OAc}$ at $\mathrm{pH} 7$. Exchangeable $\mathrm{Ca}$ and $\mathrm{Mg}$ in extracts were analyzed using Atomic Absorption Spectrophotometer, while $\mathrm{Na}$ and $\mathrm{K}$ were analyzed by 
flame photometer [48, 49]. Percentage base saturation (PBS) was calculated as percent of sum of exchangeable bases $(\mathrm{Ca}, \mathrm{Mg}, \mathrm{K}$ and $\mathrm{Na}$ ) to $\mathrm{CEC}$. Organic carbon was determined by chromate acid oxidation method [50] and available $\mathrm{S}$ by Turbidimetric method [51]. Available micronutrients ( $\mathrm{Fe}, \mathrm{Cu}, \mathrm{Zn}$ and $\mathrm{Mn}$ ) were extracted by Diethylene Triamine Pentaacetic Acid (DTPA) as described by [52] and all these micronutrients were measured by Atomic Absorption Spectrophotometer.

\subsection{Statistical Analysis}

Data were analyzed using descriptive statistics to compare the selected soil physicochemical properties in different land use systems. Correlation analyses were also conducted among soil parameters.

\section{Results and Discussion}

\subsection{Effects of Land Use on Selected Soil Physical Properties}

In this study, selected physical properties of soil such as texture, bulk density, particle density and total porosity are analyzed (Table 1). Sand, silt and clay fractions showed variations by land use system and soil depth interactions. The average textural class of the watershed is clay loam. The maximum (33.9\%) mean sand was observed on the surface layer $(0-15 \mathrm{~cm})$ of forest land followed by the surface layer of grazing land $(26.6 \%)$ while the minimum $(8.5 \%)$ in the sub-surface $(15-30 \mathrm{~cm})$ layer of cultivated land with an increase of $298.8 \%$ although the overall mean is $19.7 \%$. These high sand and silt contents of forest land might be associated with lower sand and silt erosion by surface runoff on the surface layer of forest land due to low intensity of rainfall via leaf interception of forests. Although the overall mean clay content of the watershed is $48.2 \%$, the highest $(73.4 \%)$ mean was recorded in the sub-surface $(30-45 \mathrm{~cm})$ layer of cultivated land while the lowest $(25.2 \%)$ on the surface layer of forest land by showing an increase of $191.3 \%$ which might be due to the high leaching (lessivage) of clay particles down profile in cultivated land and complexing agent of humus (OM) on the clay particles of forest land that reduce its leaching in suspension. However, in all land use systems, clay content increased while sand and silt contents decreased with increasing soil depths. These findings are in line with that of [53] who reported that overall mean soil depth showed higher sand and lower clay contents in $0-40 \mathrm{~cm}$ than in the $40-60$ $\mathrm{cm}$ soil depths at Tera Gedam watershed, northwestern Ethiopia. [54] As cited in [5] also elucidated that one of the main processes that could likely lead to textural differentiation in soil profiles is the downward movement of clay particles suspended in percolating soil water. The overall textural class of the watershed is mainly of clay loam.

Although the bulk density of Antra watershed is low with an overall mean of $1.15 \mathrm{~g} \mathrm{~cm}^{-3}$, it also showed differences by the interaction effect of land use and soil depth where relatively higher $\left(1.3 \mathrm{~g} \mathrm{~cm}^{-3}\right)$ mean bulk density was observed on the surface layer of grazing land followed $\left(1.27 \mathrm{~g} \mathrm{~cm}^{-3}\right)$ by the surface layer of cultivated land while lower $\left(0.9 \mathrm{~g} \mathrm{~cm}^{-3}\right)$ on the surface layer of forest land (Table 1) with a difference of $0.4 \mathrm{~g} \mathrm{~cm}^{-3}$. This variation in bulk density might be due to relatively high compaction by grazing animals in grazing and high OM content (more pores) in forest lands. These results are in agreement with that of $[55,5]$ who stated that lower bulk density was observed in forest land compared to cultivated and pasture lands. Similarly, [17, 18, 7] reported that virgin forest soil produced lower bulk density than the crop and pasture lands because of the well-developed fine-medium granular structure and high OM contents.

As per the classification rating suggested by [56], bulk density of the soil is rated as very low $\left(<1 \mathrm{~g} \mathrm{~cm}^{-3}\right)$, low (1 - $\left.1.3 \mathrm{~g} \mathrm{~cm}^{-3}\right)$, medium $\left(1.3-1.6 \mathrm{~g} \mathrm{~cm}^{-3}\right)$, high $(1.6-1.9 \mathrm{~g}$ $\left.\mathrm{cm}^{-3}\right)$ and very high $\left(>1.9 \mathrm{~g} \mathrm{~cm}^{-3}\right)$. Accordingly, the bulk density of Antra watershed is low. Besides, according to the proposals set by [57], the critical values of bulk density for plant growth at which root penetration is likely to be severely restricted for textural classes of sandy loam is $\left(1.8 \mathrm{~g} \mathrm{~cm}^{-3}\right)$, fine sandy loam $\left(1.7 \mathrm{~g} \mathrm{~cm}^{-3}\right)$, loam and clay loam $\left(1.6 \mathrm{~g} \mathrm{~cm}^{-3}\right)$ and clay $\left(1.4 \mathrm{~g} \mathrm{~cm}^{-3}\right)$. Based on this proposal, the average bulk density $\left(1.15 \mathrm{~g} \mathrm{~cm}^{-3}\right)$ of the soils of Antra watershed which has clay loam textural class is below the critical values for plant growth.

The particle density of the study area is generally low which might be due to its high clay particle contents (clay loam textural class). There were slight variations in particle density as a result of land use and soil depth interactions (Tables 1 ) in the watershed even though the overall average is $2.26 \mathrm{~g} \mathrm{~cm}^{-3}$. Relatively higher $(2.3 \mathrm{~g}$ $\mathrm{cm}^{-3}$ ) mean particle density was recorded on the surface layer of cultivated land and the $2^{\text {nd }}$ higher $\left(2.29 \mathrm{~g} \mathrm{~cm}^{-3}\right)$ was observed in the sub-surface $(30-45 \mathrm{~cm})$ layer of forest land while lower $\left(2.21 \mathrm{~g} \mathrm{~cm}^{-3}\right)$ in the sub-surface $(30-45 \mathrm{~cm})$ layer of grazing land with a difference of $0.11 \mathrm{~g} \mathrm{~cm}^{-3}$ between the maximum and minimum mean values. Such high content of particle density on the surface layer of cultivated land might be due to its high sand contents and presence of heavy minerals of Fe and Mn with high charge density (Table 4) which are in agreement with the findings of [15]. 
Table 1. Mean values for effects of land use and soil depth on particle sizes, bulk density, particle density and total porosity

\begin{tabular}{cccccccc}
\hline Treatments & $\begin{array}{c}\text { Sand } \\
(\%)\end{array}$ & $\begin{array}{c}\text { Silt } \\
(\%)\end{array}$ & $\begin{array}{c}\text { Clay } \\
(\%)\end{array}$ & Textural class & $\begin{array}{c}\text { Bulk Density } \\
\left(\mathrm{g} \mathrm{cm}^{-3}\right)\end{array}$ & $\begin{array}{c}\text { Particle Density } \\
\left(\mathrm{g} \mathrm{cm}^{-3}\right)\end{array}$ & $\begin{array}{c}\text { Total Porosity } \\
(\%)\end{array}$ \\
\hline C,D1 & 16.2 & 35.5 & 48.3 & Clay loam & 1.27 & 2.32 & 44.4 \\
C,D2 & 8.5 & 23.8 & 67.8 & Silt loam & 1.11 & 2.27 & 51.2 \\
C,D3 & 10.2 & 16.4 & 73.4 & Silt loam & 1.09 & 2.22 & 50.4 \\
F,D1 & 33.9 & 40.9 & 25.2 & Clay loam & 0.95 & 2.25 & 57.8 \\
F,D2 & 20.2 & 38.4 & 41.3 & Clay loam & 1.16 & 2.28 & 48.9 \\
F,D3 & 15.4 & 37.2 & 47.4 & Silty clay loam & 1.25 & 2.29 & 46.2 \\
G,D1 & 26.6 & 35.7 & 37.7 & Clay loam & 1.274 & 2.24 & 43.0 \\
G,D2 & 24.3 & 31.0 & 44.7 & Clay loam & 1.15 & 2.24 & 48.3 \\
G,D3 & 22.3 & 30.0 & 47.7 & Clay loam & 1.1 & 2.21 & 50.1 \\
\hline Mean & 19.7 & 32.1 & 48.2 & Clay loam & 1.15 & 2.26 & 48.9 \\
\hline
\end{tabular}

The mean total porosity (48.9\%) of the study area is high although it showed great differences by land use and soil depth interactions (Table 1).The highest $(57.8 \%)$ mean total porosity was observed on the surface layer of forest land and the lowest (43.0\%) on the surface layer of grazing land with an increase of $34.4 \%$ which might be due to high OM contents in forest land and relatively high compaction with high bulk density in grazing land. The results are in agreement with that of [19] who reported that conservation tillage management resulted in a better pore connectivity than conventional system. [58] Also reported that OM influences soil physical properties by encouraging granulation, assisting aggregate stability (soil structure), helping aggregation of soil particles, improving aeration and water holding capacities and reducing plasticity and cohesion. There was high significant $(\mathrm{P} \leq$ $0.001)$ and very strong negative correlation $(r=-0.97)$ between total porosity and bulk density in the study area which indicated compaction acts as a strong impediment for soil porosity, aeration and root penetration of crops. 3.1.1.Effects of Land Use on Soil Chemical Properties

\subsubsection{Soil $\mathrm{pH}$, organic carbon, total nitrogen, available sulfur and phosphorus}

In the study area, soil $\mathrm{pH}$ showed variations by the interaction effects of land use and soil depth (Table.2) although it is almost on the same range. Relatively higher (5.03) mean $\mathrm{pH}$ was observed on the surface layer of forest land and lower (4.45) on the surface layer of cultivated and grazing lands with an increase of $13 \%$ albeit the overall mean value is 4.83 . This variation in $\mathrm{pH}$ could be due to high OM with organic anions on the surface layer of forest land, and continuous removal of basic cations by harvested crops and animal grazing on the surface layers of cultivated and grazing lands, respectively. furthermore, the low $\mathrm{pH}$ in cultivated lands might be also due to the fact that of very high leaching of basic cations and clay particles from the exposed surfaces of cultivated lands and $\mathrm{H}^{+}$ion released by nitrification of $\mathrm{NH}_{4}{ }^{+}$sourced chemical fertilizers, legume roots during $\mathrm{N}_{2}$ fixation (nitrification) and roots of crops to soil solution with low OM contents on the surface layer of cultivated land.

Similar research results are found by $[59,60,20]$ who stated that soil $\mathrm{pH}$ values were significantly lower on the surface layer for cultivated soils when compared to non-cultivated soils due to the application of $\mathrm{NH}_{4}^{+}$ sourced fertilizers to cultivated lands that nitrifies $\mathrm{NH}_{4}^{+}$ and the uptake of basic cations by crops. Besides, the presence of higher $\mathrm{pH}$ in forest land might be accredited to the ameliorating effect of high content of OM that form $\mathrm{Al}$ and $\mathrm{Fe}-\mathrm{OM}$ complexes and release of hydroxyl ions as well as deposition of basic cations [5]. Besides, in sub-tropical environments, excessive disturbance of soils at seedbed preparation caused high rate of OM turnover and decomposition; through the process of oxidation, reaction of $\mathrm{CO}_{2}$ with $\mathrm{H}_{2} \mathrm{O}$ forms both organic $\left(\mathrm{H}_{2} \mathrm{CO}_{3}\right)$ and inorganic acids $\left(\mathrm{H}_{2} \mathrm{SO}_{4}, \mathrm{HNO}_{3}\right)$ which are potential suppliers of $\mathrm{H}^{+}$ions in soils and encouraging the development of acidic cations [61].

However, opposite findings are reported by [62] who stated that high $\mathrm{pH}$ values were recorded for croplands as compared to grazing and forest lands in Bale mountain areas of Ethiopia. [35] Also reported oppositely that soil $\mathrm{pH}$ decreased with increasing soil depth for the land use systems in Central highlands of Ethiopia. In this study, besides the highly significant $(\mathrm{P} \leq 0.001)$ and strong positive association $(\mathrm{r}=0.63)$ between $\mathrm{pH}$ and exchangeable $\mathrm{Mg}$, the $\mathrm{pH}$ was also significantly $(\mathrm{P} \leq 0.01)$ and positively correlated $(\mathrm{r}=0.5,0.55$ and 0.58$)$ with CEC, PBS and exchangeable Na, respectively (Table 5) which might be due to the fact that as $\mathrm{pH}$ decreases exchangeable bases such as $\mathrm{Mg}$, $\mathrm{Na}$ decrease associated with the decrease in CEC and PBS by leaching. Based on the ratings set by [63], $\mathrm{pH}$ value is rated very strongly acid $(<4.5)$, strongly acid (4.5 - 5.25), moderately acid (5.3 - 
5.9), slightly acid (6.0 - 6.6) and neutral (6.7 - 7.3). According to his proposed rating, the $\mathrm{pH}$ of the watershed is ranging from very strongly acid in cultivated to strongly acid in forest lands. Therefore, the soils of the watershed are difficult for growing acid sensitive crops unless proper management strategies are used to reduce the magnitude of acidity to a suitable range.

The watershed is medium in its OC contents with the overall mean of $2.25 \%$. However, there was great variation in OC content by the interaction effects of land use and soil depth (Table 2). The highest (4.6\%) mean OC was observed on the surface layer of forest land and the lowest $(1 \%)$ in the subsurface layer of cultivated land with an increase of $347.6 \%$ which might be due to high $\mathrm{OM}$ content on the surface layer of forest land and OM oxidation in cultivated lands. [64, 65, 53] reported that lower levels of soil OM content was observed in cultivated land. [21, 22] also indicated that clearing tropical forests and conversion into farmland lowered soil OM by $20-50 \%$ as cultivation generally aerates soil and increases OM oxidation rates. Similarly, $[66,23]$ indicated that soils lost $42-59 \%$ of their soil OC stock upon conversion from forest to crop land in the northeastern China and other areas. Organic carbon showed a decrease with the increase in soil depth in all land use systems (Table 2) which might be due to the fact that of the reduction in root residue and thereby OM contents of the soil down the profile.

Organic carbon was highly significantly $(\mathrm{P} \leq 0.001)$ and strongly positively correlated $(\mathrm{r}=0.86,0.77,0.73$ and 0.7 ) with total $\mathrm{N}, \mathrm{Zn}, \mathrm{Fe}$ and $\mathrm{Ca}$, respectively in this study (Table 5) which might be due to the fact that all of such nutrients are derived from $\mathrm{OM}$ (OM is the store house of macro and micro-nutrients such as $\mathrm{OC}$, total $\mathrm{N}$, available $\mathrm{P}$ and $\mathrm{S}$, exchangeable bases and micro-nutrients of $\mathrm{Fe}, \mathrm{Zn}$ and $\mathrm{Mn}$ ). [67] Elucidated that $\mathrm{OM}$ improved OC status and available $\mathrm{N}, \mathrm{P}, \mathrm{K}, \mathrm{S}$ and $\mathrm{CEC}$ in soils. As per the classification rating suggested by [62], $\mathrm{OC}$ for forest land (3.2\%) qualified as high while grazing $(2.3 \%)$ and cultivated (1.4\%) lands medium and low status, respectively for the study area. According to him, OC content of the soil is rated as very low $(<0.5 \%)$, low $(0.5$ $1.5 \%$ ), medium (1.5 - 3\%) and high (> 3\%). Furthermore, according to [68], OC content of the soil is rated as extremely low $(<0.4 \%)$, very low $(0.4-0.6 \%)$, low $(0.6$ $1.0 \%)$, moderate $(1.0-1.8 \%)$, high $(1.8-3.0 \%)$ and very high $(>3.0 \%)$ where the study area is felt in the high OC range based on this rating.

Similar to $\mathrm{OC}$, total $\mathrm{N}$ also indicated great variations by land use and soil depth interactions (Table 2) in the watershed in spite of the fact the overall mean value is $0.16 \%$. The overall mean $\mathrm{C}: \mathrm{N}$ ratio of the soils of the watershed is also narrow (about 14:1) that indicated low $\mathrm{OM}$ content and high degree of $\mathrm{OM}$ oxidation $/ \mathrm{N}$ mineralization. The highest $(0.28 \%)$ mean total $\mathrm{N}$ was recorded on the surface layer of forest land and the lowest
$(0.12 \%)$ in the subsurface layer of cultivated land with an increase of $133.3 \%$ which might be due to high OM content with high microbial population in the rehizosphere of forest land, and its rapid oxidation/mineralization with nitrate leaching in cultivated land, respectively. In all land use systems, total $\mathrm{N}$ decreased with increasing soil depth which might be again due to the reduction in OM contents, microbial biomass and $\mathrm{N}$ mineralization down the profile. According to the ratings suggested by [56], the $\mathrm{C}: \mathrm{N}$ ratio of $<10$ very low, $10-15$ low, 15 - 25 medium, $25-70$ high, $70-100$ very high, 100 extremely high and 860 approximate end point. Based on this proposal, the soil of Antra watershed is rated as medium in $\mathrm{C}: \mathrm{N}$ ratio.

These results are in agreement with that of $[22,20]$ who reported that changes in soil OM could lead to changes in total $\mathrm{N}$ and long term cultivation without organic fertilizers usually leads to a decrease in soil OC and total $\mathrm{N}$ contents because organic forms generally account for more than $95 \%$ of soil N. Similarly, [24, 69, 25] elucidated that the contribution of OM to the total $\mathrm{N}$ is high and soil $\mathrm{N}$ content decreased by 64 and $55 \%$ in cultivated sites compared to native forest and rangelands, respectively by which afforestation also increased total N. However, [55] reported that pasture soil contained the highest $\mathrm{N}$ stocks than forest and cultivated lands on the top $5 \mathrm{~cm}$ layer. [59] Also reported that total $\mathrm{N}$ was high on the surface layer of forest land but reduced with increasing soil depth by $50 \%$ for each subsequent depth increment in both cultivated and non-cultivated soils.

In this study, total $\mathrm{N}$ was negatively correlated $(\mathrm{r}=$ -0.21) with soil $\mathrm{pH}$ which might be due to slow rate of $\mathrm{OM}$ oxidation or $\mathrm{N}$ mineralization as microorganisms especially nitrifying bacteria (Rhizobium) are sensitive to the acidic environments and/or $\mathrm{H}^{+}$release (protoniization) by nitrification when high ammonium sourced $\mathrm{N}$ fertilizer is applied to the soils (Table 5). Based on [70], total $\mathrm{N}$ content is rated as low $(<0.15 \%)$, medium $(0.15$ $0.25 \%)$ and high (>0.25\%). Therefore, according to the ratings suggested by him, forest $(0.22 \%)$ and grazing $(0.19 \%)$ lands qualified for medium while cultivated $(0.14 \%)$ land qualified low in its total $\mathrm{N}$ status in this study although the overall mean $(0.16 \%)$ is rated as medium. Furthermore, [71], proposed rates of total $\mathrm{N}$ as very low $(<0.05 \%)$, low $(0.05-0.15)$, medium $(0.15-$ $0.25 \%)$, high $(0.25-0.50 \%)$ and very high $(>0.5 \%)$.

Soils of Antra watershed are low in its available $\mathrm{S}$ contents with an overall mean of $5.7 \mathrm{ppm}$. However, high variation was observed in available $\mathrm{S}$ by the interaction effects of land use and soil depth where the highest (11.1 $\mathrm{ppm})$ mean was observed on the surface layer of forest land and the lowest $(2.8 \mathrm{ppm})$ in the subsurface layer of cultivated land that showed an increase of $293.9 \%$ which might be due to high $\mathrm{OM}$ contents and $\mathrm{pH}$ values on the surface layer of forest land (Table 2). Besides, the low content of available $\mathrm{S}$ in cultivated land might be due to its low $\mathrm{pH}$ value and high clay content for sulfate fixation, 
leaching/soil erosion, low OM contents and crops uptake as well as management problems. Available $\mathrm{S}$ had shown slight reduction with increasing soil depth in all land use systems (Table 2) which might be due to the reduction in OM contents, and its high solubility and rapid leaching beyond the soil depths that were studied. [72] Revealed that deforestation of natural forests and subsequent cultivation invariably led to large losses of organic $\mathrm{S}$ in sub-humid Ethiopian highlands.

These results are also supported in one way or another by [73] who stated that FYM application increased OC and S contents of soil in which up to $98 \%$ of total soil S may be present as organic S compounds. [15] Also reported that the highest total $\mathrm{S}$ was observed on the surface layer of virgin land and decreased with soil depth due to low OM contents. Similarly, [26, 27] reported that intensive cropping resulted in higher S removal and depletion in soils. Furthermore, [74] elucidated that since much of $\mathrm{S}$ is held in organic fraction of soils, maintenance of $\mathrm{OM}$ at an adequate level in soil is an effective practice in preventing $\mathrm{S}$ deficiency in the field crops.

Based on the report of [75], the critical level of available $\mathrm{S}$ is $6.5 \mathrm{ppm}$ for optimum crop production although $[76,77]$ reported $10 \mathrm{ppm}$ as the critical threshold value for most crops for available $\mathrm{S}\left(\mathrm{SO}_{4}{ }^{2-}\right)$ in the soil. Moreover, [78] reported that cereals do not respond to $\mathrm{S}$ application when $\mathrm{S}$ level in soil is in the range of $6-8 \mathrm{ppm}$, and overall adequate $\mathrm{S}$ levels for cereals may be around $7 \mathrm{ppm}$. Besides, $20 \mathrm{ppm} \mathrm{SO}_{4}{ }^{2-}-\mathrm{S}$ content is the critical limit adopted for Ethiopian soils [79]. Cultivated soil of the study area, therefore, is below the critical level that needs S sourced fertilizers mainly organic sources as soils of the watershed is acidic with low OM contents. In this study, available $\mathrm{S}$ was also highly significantly $(\mathrm{P} \leq 0.001)$ and strongly positively correlated $(\mathrm{r}=0.680 .73$ and 0.78$)$ with $\mathrm{OC}$, $\mathrm{CEC}$ and $\mathrm{Zn}$, respectively (Table 5). This might be due to the fact that OM is the source or store house of all of these and other essential plant nutrients when it decomposes by microbial activities of the soil. [80] Reported similar results that the profile of organic S content generally follows the pattern of OM in soils with soil depth.

Available P contents of the soils of Antra watershed is very low with an overall mean of $3.5 \mathrm{ppm}$ and showed variations by the interaction effects of land use and soil depth (Table 2). The highest (5.5 ppm) mean available $\mathrm{P}$ was recorded on the surface layer of cultivated land and the lowest $(2.2 \mathrm{ppm})$ in the subsurface of cultivated land with an increase of $150 \%$ which might be due to the application of DAP fertilizer (although its rate of application is low), its release from adsorbed colloidal surfaces, and mychorhizal fungi activity on the surface layer and its less mobility to the subsoil layer of cultivated land. These results are in agreement with that of $[15,6]$ who indicated that available $\mathrm{P}$ in cultivated land was higher than grazing and forest lands. Similarly, [19] reported that mineral $\mathrm{P}$ fertilization resulted in the building up of plant available $\mathrm{P}$ on top soils compared to non-fertilized plots and decreased with increasing soil depths [81, 59]. Furthermore, [82] estimated that only $20 \%$ of applied $\mathrm{P}$ fertilizer is taken up by crops in the year of application and the remainder is fixed in soils in various degrees of availability to the succeeding crops. [83, 84] reported that threshold soil test for Olsen $\mathrm{P}$ values for agronomic and environmental purposes are 12 and $>50$ ppm.

There was significant $(\mathrm{P} \leq 0.01)$ and positive correlation $(\mathrm{r}=0.58)$ between available $\mathrm{P}$ and total $\mathrm{N}$ as shown in Table 2 which might be due to the fact that as $\mathrm{N}$ increase in the soil, plants grow luxuriously with high remains of roots that act as additional source of soil P by microbial decomposition. Based on the rating set by [85] of Bray test, the available P content of cultivated (3.9 $\mathrm{ppm})$, forest (3.5 ppm) and grazing (3.2 ppm) lands of the watershed is low that urges high application of $\mathrm{P}$ sourced fertilizers (inorganic or organic). According to this suggestion, available $\mathrm{P}$ content of the clay loam soil is rated as low $(0-10 \mathrm{ppm})$, medium $(10-20 \mathrm{ppm})$ and high (>20 ppm).

Table 2. Mean values for effects of land use and soil depth on $\mathrm{pH}$, organic carbon, total nitrogen, available phosphorus and sulfur

\begin{tabular}{cccccc}
\hline Treatments & $\mathrm{pH}$ & $\begin{array}{c}\text { Available sulfur } \\
(\mathrm{ppm})\end{array}$ & Organic carbon (\%) & Total nitrogen (\%) & $\begin{array}{c}\text { Available } \\
\text { phosphorus }\end{array}$ \\
\hline C,D1 & 4.45 & 2.9 & 1.84 & 0.16 & 5.5 \\
C,D2 & 4.86 & 2.9 & 1.27 & 0.15 & 4.1 \\
C,D3 & 4.98 & 2.8 & 1.03 & 0.12 & 2.2 \\
F,D1 & 5.03 & 11.1 & 4.61 & 0.28 & 3.8 \\
F,D2 & 4.93 & 10.1 & 2.45 & 0.19 & 3.7 \\
F,D3 & 4.95 & 9.1 & 2.00 & 0.18 & 3.0 \\
G,D1 & 4.45 & 4.4 & 2.90 & 0.27 & 2.9 \\
G,D2 & 4.84 & 4.3 & 2.18 & 0.16 & 3.1 \\
G,D3 & 5.00 & 4.1 & 1.93 & 0.14 & 3.5 \\
\hline Mean & 4.83 & 5.7 & 2.25 & 0.16 & 3.5 \\
\hline
\end{tabular}


3.1.1.2. Cation exchange capacity, exchangeable bases (Ca, $\mathrm{Mg}, \mathrm{K}$ and $\mathrm{Na}$ ) and percentage base saturation

Although the overall mean CEC of the watershed is high, there was variation in CEC by the interaction effects of land use and soil depth in the watershed (Table 3). The highest $\left(42.2 \mathrm{cmolc}^{-1}\right)$ CEC was recorded on the surface layer of forest land while the lowest $(31.6 \mathrm{cmolc}$ $\mathrm{kg}^{-1}$ ) on the surface layer of cultivated land with an increase of $33.5 \%$ which might be due to high OM content and $\mathrm{pH}$ on the surface layer of forest land, and low $\mathrm{OM}$, high leaching and uptake of basic cations as well as leaching of clay particles from cultivated land with lower $\mathrm{pH}$. $[86,17,29]$ reported that when humus is combined with clay, it increased soil CEC, and plant residues with OC content of $40-50 \%$ have increased soil's negative charge while low $\mathrm{pH}$ reduces CEC. [87, 88] stated that CEC is highly and positively correlated with OM, clay and $\mathrm{pH}$ but affected negatively by intensive cultivation. There was significant $(\mathrm{P} \leq 0.01)$ and positive correlation $(\mathrm{r}$ $=0.58$ ) between $\mathrm{CEC}$ and $\mathrm{OC}$ in this study. Analogous to $\mathrm{OC}$, there was also significant $(\mathrm{P} \leq 0.001)$ and strong positive associations $(\mathrm{r}=0.76,0.73,0.65$ and 0.66$)$ between $\mathrm{CEC}$, and exchangeable $\mathrm{Ca}$, available $\mathrm{S}$, exchangeable $\mathrm{Mg}$ and available $\mathrm{Zn}$, respectively (Table 5). These high associations between CEC and OC as well as other nutrients might be due to the fact that $\mathrm{OM}$ is the reserve of all these nutrients through its decomposition by microorganisms besides to the store house of basic cations (which are base for CEC). According to the suggestions made by [89], the CEC of the soil is rated as very low $(<5$ cmolc $\left.\mathrm{kg}^{-1}\right)$, low $\left(5-15 \mathrm{cmolc} \mathrm{kg}^{-1}\right)$, medium (15 - 25 cmolc $\left.\mathrm{kg}^{-1}\right)$, high ( $25-40$ cmolc $\left.\mathrm{kg}^{-1}\right)$ and very high (> 40 cmolc $\mathrm{kg}^{-1}$ ). Based on this rating, soils of the study area is high in CEC content with an overall average of 36.4 cmolc $\mathrm{kg}^{-1}$.

Exchangeable $\mathrm{Ca}$ also showed variations in Wujiraba watershed by the interaction effects of land use and soil depth (Table 3) with an overall mean of $15.2 \mathrm{cmolc} \mathrm{kg}^{-1}$. The highest exchangeable $\mathrm{Ca}\left(22.2 \mathrm{cmolc} \mathrm{kg}^{-1}\right)$ was observed on the surface layer of forest land where as the lowest $\left(8.6 \mathrm{cmolc}^{-1}\right)$ on the surface layer of cultivated land with an increase of $158 \%$ which might be due to high OM content with colloidal surface and store house of basic cations as well as relatively high $\mathrm{pH}$ on the surface layer of forest land, and exchangeable $\mathrm{Ca}$ leaching and crop uptake from the surface layer of cultivated land. In cultivated land, exchangeable Ca showed an increase with the increase in soil depth while in forest land it decreased down the profile (Table 3) which might be due to the fact that of its high leaching in cultivated land, and low leaching by high rainfall interception of leaves as well as high OM contents (strong reserve of exchangeable $\mathrm{Ca}$ ) of forest land, respectively. Analogous findings are reported by $[29,30]$ who elucidated that cultivation led to the reduction, uptake and leaching of exchangeable cations, especially in acidic tropical soils.
In this study, exchangeable $\mathrm{Ca}$ showed highly significant $(\mathrm{P} \leq 0.001)$ and strong positive correlation $(\mathrm{r}=$ 0.7 and 0.9 ) with OC and PBS, respectively (Table 5) which might be due to its source from OM and it is one of the most abundant basic cations surrounding the colloidal soil surface with higher charge density and shorter radi. According to the ratings recommended by [89], the soil is ranged medium in cultivated land to very high in forest land in its exchangeable $\mathrm{Ca}$ content. Based on this proposed rating, exchangeable $\mathrm{Ca}$ of the soil is rated as very low $\left(<2 \mathrm{cmolc} \mathrm{kg}^{-1}\right)$, low $\left(2-5\right.$ cmolc kg$\left.{ }^{-1}\right)$, medium $\left(5-10\right.$ cmolc $\left.\mathrm{kg}^{-1}\right)$, high $\left(10-20\right.$ cmolc $\left.\mathrm{kg}^{-1}\right)$ and very high $\left(>20 \mathrm{cmolc} \mathrm{kg}^{-1}\right)$.

There was also variation in exchangeable $\mathrm{Mg}$ content in the watershed by the interaction effect of land use and soil depth where the highest $\left(8.1 \mathrm{cmolc} \mathrm{kg}^{-1}\right)$ was observed in the subsurface layer of forest land and the lowest (1.4 cmolc $\mathrm{kg}^{-1}$ ) on the surface layer of cultivated land (Table 3) that indicated a decrease of $82.7 \%$ which might be due to low $\mathrm{OM}$ content, low $\mathrm{pH}$, high plant uptake and leaching of exchangeable $\mathrm{Mg}$ from cultivated land. [10] Reported that the lowest exchangeable $\mathrm{Mg}$ was recorded in cultivated land which could be due to high intensity of cultivation and abundant crop harvest with little or no use of inputs. Exchangeable Mg had increased with increasing soil depth in all land use systems (Table 3 ) which might be due to the effect of its leaching down the profile. The value of exchangeable $\mathrm{Mg}$ in the study area was highly significantly $(\mathrm{P} \leq 0.001)$ and strongly positively correlated $(r=0.65$ and 0.73$)$ with CEC and PBS, respectively (Table 5) which might be due to the fact that exchangeable $\mathrm{Mg}$ is part of exchangeable bases for increasing CEC and PBS in any soil. According to [89] rating, soils of the study area are rated medium in cultivated land and very high in forest land in its exchangeable Mg content. Based on this proposed rating, exchangeable $\mathrm{Mg}$ of the soil is rated as very low $(<0.3$ cmolc kg-1), low $\left(0.3\right.$ - 1.0 cmolc kg $\left.^{-1}\right)$, medium (1.0 - 3.0 cmolc $\left.\mathrm{kg}^{-1}\right)$, high $\left(3.0-8.0 \mathrm{cmolc} \mathrm{kg}^{-1}\right)$ and very high (> $8.0 \mathrm{cmolc} \mathrm{kg}^{-1}$ ). Based on the suggestions set by [90], the Ca: $\mathrm{Mg}$ ratio of the soil is rated as Ca deficient $(<1)$, low $\mathrm{Ca}(1-4)$, balanced (4 - 6), low Mg (6 - 10) and $\mathrm{Mg}$ deficient (> 10). According to this proposal, the $\mathrm{Ca}: \mathrm{Mg}$ ratio $(2.98: 1)$ of the soils of Antra watershed is qualified under low exchangeable $\mathrm{Ca}$ level.

Although the overall mean of exchangeable $\mathrm{K}$ of the watershed is $0.56 \mathrm{cmolc} \mathrm{kg}^{-1}$, difference was observed in exchangeable $\mathrm{K}$ by the land use and soil depth interactions (Table.3). The highest $\left(0.76 \mathrm{cmolc} \mathrm{kg}^{-1}\right)$ exchangeable $\mathrm{K}$ was recorded on the surface layer of forest land while the lowest $\left(0.31 \mathrm{cmolc} \mathrm{kg}^{-1}\right)$ in the subsurface layer of grazing land which might be due to low plant uptake on the forest land and relatively high compaction or bulk density in grazing land that restricts its downward movement as well as its uptake by freshly growing grasses. Exchangeable K content of cultivated land is somewhere in between forest 
and grazing lands although it is mined by growing crops. This result is in agreement with that of $[29,15]$ who found lower exchangeable $\mathrm{K}$ contents in cultivated and grazing lands than forest land. [91] reported that the critical level of exchangeable $\mathrm{K}$ in the soil for most crops for $\mathrm{K}$ fertilizer requirement is $0.38 \mathrm{cmolc} \mathrm{kg}^{-1}$ and therefore, the content of exchangeable $\mathrm{K}$ is above the threshold level in the soils of the study area for crop growth with no $\mathrm{K}$ fertilizer requirement in the plow layer of cultivated lands which might be due to volcanic (ash) sources of basaltic sourced soils. Similarly, [92] reported that crop responses to $\mathrm{K}$ fertilization are rare in Africa due to high exchangeable $\mathrm{K}$ contents in many parts of Africa including Ethiopia. Furthermore, according to the suggestions set by [89], exchangeable $\mathrm{K}$ of the soil is rated as very low $\left(<0.2 \mathrm{cmolc}^{-1}\right)$, low $(0.2-0.3 \mathrm{cmolc}$ $\left.\mathrm{kg}^{-1}\right)$, medium ( $\left.0.3-0.6 \mathrm{cmolc} \mathrm{kg}^{-1}\right)$, high $(0.6-1.2 \mathrm{cmolc}$ $\left.\mathrm{kg}^{-1}\right)$ and very high $\left(>1.2 \mathrm{cmolc} \mathrm{kg}^{1}\right)$.

Exchangeable $\mathrm{Na}$ indicated variations in the watershed by the land use and soil depth interactions (Tables 3) although the overall mean is $0.37 \mathrm{cmolc} \mathrm{kg}^{-1}$. The highest exchangeable $\mathrm{Na}\left(0.55 \mathrm{cmolc}^{-1}\right)$ was recorded on the surface layer of forest land and the lowest $(0.19 \mathrm{cmolc}$ $\mathrm{kg}^{-1}$ ) on the surface layer of cultivated land that increased by $205.3 \%$ which might be due to low erosion/leaching in forest land by leaf interceptions of the high rainfall intensity and high leaching (longer radi and lower charge density) in cultivated land. According to [89] rating, soils of the study area qualified as low $\left(0.23 \mathrm{cmolc} \mathrm{kg}^{-1}\right)$ in cultivated land and medium ( 0.46 and 0.44 cmolc kg-1 $)$ in forest and grazing lands, respectively for their exchangeable Na contents. Based on the ratings of this source, exchangeable $\mathrm{Na}$ of the soil is rated as very low $(<$ $\left.0.1 \mathrm{cmolc} \mathrm{kg}^{-1}\right)$, low $\left(0.1-0.3 \mathrm{cmolc} \mathrm{kg}^{-1}\right)$, medium $(0.3-$ 0.7 cmolc $\left.\mathrm{kg}^{-1}\right)$, high $(0.7-2$ cmolc kg-1) and very high (> 2 cmolc kg-1).

The binding is stronger the higher the charge of ions (charge density) i.e. trivalent cations are more strongly bound than divalent cations, which in turn are more tightly held than monovalent cations on the colloidal surfaces. Exchangeable $\mathrm{Ca}$ and $\mathrm{Mg}$, therefore, were by far higher than exchangeable $\mathrm{K}$ and $\mathrm{Na}$ in all land uses of the study area since divalent cations (shorter radii) were higher than monovalent once which was similar to the report of [30]. Similarly, [93] elucidated that as a result of small energy of adsorption of $\mathrm{K}$ and $\mathrm{Na}$, it is more likely to exist in soil solution than colloidal sites and be removed from soil by leaching. [16] Also reported that deforestation, leaching, limited recycling of dung and crop residues, declining fallow periods and soil erosion have contributed to depletion of basic cations and reduction of CEC in cultivated land as compared to adjacent forest land.

Percentage base saturation also showed variations in the watershed by the land use and soil depth interactions (Table 3) albeit the overall mean is high (57.5\%). In this study, the highest PBS (73.5\%) was observed in the subsurface layer of forest land whereas the lowest (34.4\%) on the surface layer of cultivated land with an increase of $67.2 \%$ which might be due to relatively high $\mathrm{OM}$ and clay contents (soil colloidal sites and storehouse of exchangeable bases) in the subsurface layer of forest land compared to the surface layers of cultivated and grazing lands. According to the ratings proposed by $[94,56]$, the average PBS (57.5\%) of Antra watershed is moderate as the proposed ratings of them indicates that PBS of $0-20 \%$ very low, $20-40 \%$ low, $40-60 \%$ medium, $60-80 \%$ high and $>80 \%$ very high. Similarly, based on the ratings set by [95], PBS as a criterion of leaching, soils are rated as very weakly leached $(70-100 \%)$, weakly leached $(50-70 \%)$, moderately leached $(30-50 \%)$, strongly leached $(15-30 \%)$ and very strongly leached $(0-15 \%)$. Accordingly, the overall mean of the PBS $(57.5 \%)$ of soils of the watershed is rated as weakly leached while cultivated land $(46.1 \%)$ is qualified as moderately leached.

Table 3. Mean values for effects of land use and soil depth on cation exchange capacity, exchangeable bases and percentage base saturation

\begin{tabular}{|c|c|c|c|c|c|c|}
\hline \multirow[t]{2}{*}{ Treatments } & \multirow{2}{*}{$\begin{array}{c}\text { Cation exchange } \\
\text { capacity }(\mathrm{cmol}(+) \\
\mathrm{kg}^{-1} \\
\end{array}$} & \multicolumn{4}{|c|}{ Exchangeable bases $\left(\mathrm{cmol}^{(}+\right) \mathrm{kg}^{-1}$} & \multirow{2}{*}{$\begin{array}{c}\text { Percentage base } \\
\text { saturation }(\%)\end{array}$} \\
\hline & & Calcium & Magnesium & Potassium & Sodium & \\
\hline $\mathrm{C}, \mathrm{D} 1$ & 31.6 & 8.6 & 1.4 & 0.71 & 0.19 & 34.4 \\
\hline $\mathrm{C}, \mathrm{D} 2$ & 33.5 & 11.1 & 4.5 & 0.48 & 0.21 & 48.7 \\
\hline $\mathrm{C}, \mathrm{D} 3$ & 35.1 & 12.1 & 5.6 & 0.45 & 0.28 & 52.3 \\
\hline $\mathrm{F}, \mathrm{D} 1$ & 42.2 & 22.2 & 6.3 & 0.77 & 0.55 & 70.5 \\
\hline $\mathrm{F}, \mathrm{D} 2$ & 37.4 & 19.3 & 7.1 & 0.58 & 0.49 & 73.5 \\
\hline F,D3 & 39.9 & 15.2 & 8.1 & 0.59 & 0.33 & 60.6 \\
\hline G,D1 & 34.8 & 14.1 & 2.2 & 0.68 & 0.31 & 49.8 \\
\hline G,D2 & 36.0 & 17.2 & 4.9 & 0.47 & 0.50 & 63.9 \\
\hline G,D3 & 37.2 & 17.1 & 5.9 & 0.31 & 0.51 & 63.9 \\
\hline Mean & 35.4 & 15.2 & 5.1 & 0.56 & 0.37 & 57.5 \\
\hline
\end{tabular}

3.1.1.3. Micronutrients (extractable iron, manganese,

copper and zinc) 
Variations were shown in the extractable micronutrients of $\mathrm{Fe}, \mathrm{Mn}$ and $\mathrm{Zn}$ content in Antra watershed by the interaction effects of land use and soil depth where the highest (14.2, 24.1 and $2.9 \mathrm{ppm}$ ) were observed on the surface layer of forest land (Table 4), respectively which might be due to high OM concentrations that acted as a chelating effect and source of such nutrients as well as low $\mathrm{pH}$ (strong soil acidity) of the area. Difference was also observed in the $\mathrm{Cu}$ content by which the highest $(2.7$ ppm) was recorded on the surface layer of forest land that might be also due to its high OM contents. [16] Reported that OM may promote the availability of such nutrients by supplying soluble complexing agents or carbonic $\left(\mathrm{H}_{2} \mathrm{CO}_{3}\right)$ and nitric $\left(\mathrm{HNO}_{3}\right)$ acids (product of $\mathrm{OM}$ oxidation) that interfere with their fixation. These results are also supported by $[15,6]$ who stated that micronutrients content increased with the increase in OM contents. [96] Also notified that OM such as FYM have traditionally been used and supplied all major nutrients necessary for plant growth, as well as micronutrients (Fe, $\mathrm{Mn}, \mathrm{Cu}$ and $\mathrm{Zn})$. However, [97] reported that available $\mathrm{Fe}, \mathrm{Mn}, \mathrm{Cu}$ and
Zn status of fertilized plots with macronutrient elements were depleted as such nutrients were utilized from the soils to meet the requirements of crops. In this study, available $\mathrm{Fe}, \mathrm{Mn}, \mathrm{Cu}$ and $\mathrm{Zn}$ had significant $(\mathrm{P} \leq 0.05)$ and strong positive correlation $(\mathrm{r}=0.73,0.44,0.57$ and 0.77 ) with $\mathrm{OC}$ in their orders (Table 5) which might be due to the fact that $\mathrm{OM}$ is the store house/reserve of micronutrients and $\mathrm{OC}$ via microbial decomposition.

The range in critical level values of extractable micronutrients has been given by [98] as Fe (2.5 - 5.0 ppm), Mn (1.0 - $5.0 \mathrm{ppm}), \mathrm{Cu}(0.1-2.5 \mathrm{ppm})$ and $\mathrm{Zn}(0.2$ - 2.0 ppm). Extractable $\mathrm{Cu}$ of $0.9 \mathrm{ppm}$ is the critical limit adopted for Ethiopian soils [79]. Based on the suggestions made by them, soils of the study area are affected by $\mathrm{Fe}$ (10.2 ppm) and $\mathrm{Mn}$ (13.7 ppm) toxicity but not by $\mathrm{Cu}(2.1$ $\mathrm{ppm})$ and $\mathrm{Zn}(0.93 \mathrm{ppm})$ metals for producing crops in these acidic soils. [61] Also indicated that the solubility, availability and plant uptake of micronutrient cations $(\mathrm{Cu}$, $\mathrm{Fe}, \mathrm{Mn}$ and $\mathrm{Zn}$ ) are more under acidic conditions ( $\mathrm{pH}$ of 5.0 to 6.5 ) than alkaline soil reaction just like that of soils of the study area.

Table 4. Mean values for effects of land use and soil depth on extractable iron, manganese, copper and zinc

\begin{tabular}{|c|c|c|c|c|c|}
\hline Treatments & $\begin{array}{l}\text { Available iron } \\
\text { (ppm) }\end{array}$ & $\begin{array}{l}\text { Available manganese } \\
\text { (ppm) }\end{array}$ & $\begin{array}{l}\text { Available } \\
\text { (ppm) }\end{array}$ & copper & $\begin{array}{l}\text { Available zinc } \\
\text { (ppm) }\end{array}$ \\
\hline C,D1 & 7.2 & 21.2 & 2.38 & & 0.89 \\
\hline $\mathrm{C}, \mathrm{D} 2$ & 6.4 & 13.7 & 1.81 & & 0.49 \\
\hline C,D3 & 4.5 & 12.6 & 1.61 & & 0.41 \\
\hline F,D1 & 14.2 & 24.1 & 2.71 & & 2.85 \\
\hline $\mathrm{F}, \mathrm{D} 2$ & 11.8 & 16.9 & 2.58 & & 1.34 \\
\hline F,D3 & 12.8 & 14.8 & 2.46 & & 1.07 \\
\hline G,D1 & 12.6 & 14.1 & 2.23 & & 0.38 \\
\hline G,D2 & 11.1 & 3.5 & 1.60 & & 0.55 \\
\hline G,D3 & 11.2 & 2.8 & 1.55 & & 0.39 \\
\hline Mean & 10.2 & 13.7 & 2.1 & & 0.93 \\
\hline
\end{tabular}


Table 5. Pearson's correlation matrix for various soil physicochemical parameters

\begin{tabular}{|c|c|c|c|c|c|c|c|c|c|c|c|c|c|c|c|c|c|}
\hline & $\mathrm{p}_{\mathrm{b}}$ & $f$ & $\mathrm{pH}$ & CEC & OC & TN & $A v P$ & Av $S$ & $\mathrm{Ca}$ & $\mathrm{Mg}$ & K & $\mathrm{Na}$ & PBS & $\mathrm{Fe}$ & Mn & $\mathrm{Cu}$ & $\mathrm{Zn}$ \\
\hline$\hat{\mathrm{b}}_{\mathrm{b}}$ & 1.0 & & & & & & & & & & & & & & & & \\
\hline$f$ & $-0.97 * * *$ & 1.0 & & & & & & & & & & & & & & & \\
\hline $\mathrm{pH}$ & $-0.51 * *$ & 0.47 & 1.0 & & & & & & & & & & & & & & \\
\hline CEC & $-0.46^{*}$ & $0.48 * *$ & $0.5^{* *}$ & 1.0 & & & & & & & & & & & & & \\
\hline$O C$ & -0.32 & 0.34 & 0.04 & $0.58 * *$ & 1.0 & & & & & & & & & & & & \\
\hline TN & -0.08 & 0.08 & -0.21 & $0.42 *$ & $0.86 * * *$ & 1.0 & & & & & & & & & & & \\
\hline$A v P$ & -0.46 & -0.08 & -0.24 & 0.3 & 0.11 & $0.58 * *$ & 1.0 & & & & & & & & & & \\
\hline Av $S$ & -0.23 & 0.31 & 0.33 & $0.73 * * *$ & $0.68 * * *$ & $0.55 * *$ & -0.06 & 1.0 & & & & & & & & & \\
\hline $\mathrm{Ca}$ & $-0.52 * *$ & $0.49 * *$ & $0.45^{*}$ & $0.76^{* * *}$ & $0.7 * * *$ & $0.45^{*}$ & -0.25 & $0.68 * * *$ & 1.0 & & & & & & & & \\
\hline $\mathrm{Mg}$ & -0.34 & $0.4^{*}$ & $0.63 * * *$ & $0.65^{* * *}$ & 0.05 & 0.12 & -0.37 & $0.59 * *$ & $0.47^{*}$ & 1.0 & & & & & & & \\
\hline K & 0.01 & 0.05 & 0.37 & 0.13 & $0.57 * *$ & $0.74 * * *$ & 0.29 & $0.47^{*}$ & 0.03 & -0.16 & 1.0 & & & & & & \\
\hline $\mathrm{Na}$ & -0.35 & 0.28 & $0.55^{* *}$ & $0.59 * *$ & $0.51 * *$ & 0.24 & -0.16 & $0.48 *$ & $0.8^{* * *}$ & 0.34 & -0.22 & 1.0 & & & & & \\
\hline PBS & $-0.48^{*}$ & $0.46 *$ & $0.58 * *$ & $0.64 * * *$ & $0.44 *$ & 0.18 & -0.35 & $0.66 * * *$ & $0.9^{* * *}$ & $0.73 * * *$ & -0.14 & $0.72 * *$ & 1.0 & & & & \\
\hline $\mathrm{Fe}$ & -0.06 & 0.08 & -0.03 & $0.61 * * *$ & $0.73 * * *$ & $0.65 * * *$ & -0.07 & $0.68 * * *$ & $0.7^{* * *}$ & 0.33 & 0.31 & 0.44 & $0.59 * *$ & 1.0 & & & \\
\hline $\mathrm{Mn}$ & -0.06 & 0.15 & -0.21 & 0.14 & $0.44 *$ & $0.51 * *$ & $0.4^{*}$ & $0.45^{*}$ & -0.03 & -0.07 & $0.88 * * *$ & -0.27 & -0.15 & 0.08 & 1.0 & & \\
\hline $\mathrm{Cu}$ & 0.03 & 0.08 & -0.18 & 0.26 & $0.57 * *$ & $0.59 * *$ & 0.3 & $0.62 * * *$ & 0.21 & 0.07 & $0.74 * * *$ & -0.08 & $0.77 * * *$ & 0.48 & 0.77 & 1.0 & \\
\hline $\mathrm{Zn}$ & $-0.46 *$ & $0.53^{* *}$ & 0.2 & $0.65^{* * *}$ & $0.77 * * *$ & $0.58^{* *}$ & 0.21 & $0.78 * * *$ & $0.57 * *$ & 0.33 & $0.59 * *$ & 0.31 & $0.68 * * *$ & $0.5^{* *}$ & $0.68^{* * *}$ & 0.3 & 1.0 \\
\hline
\end{tabular}

*** Significant at $\mathrm{P}=0.001$; ** significant at $\mathrm{P}=0.01$; * significant at $\mathrm{P}=0.05$ levels; $\mathrm{TN}=$ total nitrogen; Av. $\mathrm{P}=$ available $\mathrm{P} ; \mathrm{Av} . \mathrm{S}=$ available $\mathrm{S}$ 


\section{Conclusions}

Land use systems have strong effects on the soil fertility status of an area where cultivated field showed nutrient depletion. Forest land should have been given special attention as it is the base for keeping soil more fertile by serving as the store house of nutrients. In this study, forest land was found to be low in bulk density, high in total porosity and better in $\mathrm{OC}$, total $\mathrm{N}$, and available S, CEC, exchangeable bases and extractable micronutrients content especially on its surface layer than grazing and cultivated lands. Although it is clay loam in texture and relatively better in available $\mathrm{P}$ than grazing and forest lands, cultivated land is poorer in plant nutrients content which has become constraints for crop production. This signals the great need for plant nutrient amelioration measures such as integrated nutrient management (application of organic and inorganic fertilizers), growing of $\mathrm{N}_{2}$ fixing crops and application of agro-forestry into farming systems so that soil total porosity, $\mathrm{pH}, \mathrm{OC}$, total $\mathrm{N}$, available $\mathrm{S}$ and $\mathrm{P}, \mathrm{CEC}$, exchangeable bases and micronutrients content will be improved for enhanced production of sufficient food for farm households by minimizing nutrient depletion and keeping such acidic soils fertile.

There should be an improvement of the fertility status cultivated lands by applying nutrient rich amendments such as organic matter which have environmentally friendly, socially acceptable and economically feasible. In order to increase its fertility and carrying capacity of the grazing lands, there should not be used in overgrazing but in control grazing by dividing the area in to blocks by making fences that allow fallowing. The forest lands should be also conserved in different ways such as making area closure, game reserves and the like to make an area ecologically conducive.

\section{Acknowledgements}

I acknowledge the staff members, especially laboratory technicians at Bahir Dar Soil Testing and Fertility Improvement Center for their logistic and technical supports during analysis of soil samples. I also acknowledge Amhara National Regional State Agriculture Bureau and Council Office for its logistic support. Last but not least, I would also thank Samara University in general and Department of Natural Resources Management in particular for its tremendous supports that offered.

\section{REFERENCES}

[1] Sanchez, P.A. and Jama, B.A. 2002. Soil fertility replenishment takes off in East and Southern 9Africa. In: Integrated Plant Nutrient Management in sub-Saharan Africa: From concept to practice. B. Vanlauwe, J. Diels, N. Sanginga and R. Merckx (Eds.). CAB Int., Wallingford, UK. pp.23 - 45 .

[2] Henao, J. and Baanante, C. 2006. Agricultural Production and Soil Nutrient Mining in Africa: Implication for Resource Conservation and Policy Development. IFDC Tech. Bull. International Fertilizer Development Center. Muscle Shoals, Al. USA.pp.1-75.

[3] Hurni, H. 1993. Land Degradation, Famine and Land Resource Scenarios in Ethiopia. In: D. Pimentel (ed), World Soil Erosion and Conservation. Cambridge University press. pp. 27-62.

[4] Wondwosen T. and Sheleme, B. 2011. Identification of growth limiting nutrient(s) in Alfisols: Soil physico-chemical properties, nutrient concentrations and biomass yield of maize. American Journal of Plant Nutrition and Fertilization Technology, 1: 23 - 35.

[5] Abreha, K. 2013. Soil Acidity Characterization and Effects of Liming and Chemical Fertilization on Dry Matter Yield and Nutrient Uptake of Wheat (Triticum aestivum L.) on Soils of Tsegede District, Northern Ethiopia. PhD Dissertation, Haramaya University, Haramaya, Ethiopia.

[6] Gebeyaw, T. 2007. Soil Fertility Status as Influenced by Different Land Uses in Maybar Areas of South Wello zone, North Ethiopia. MSc. Thesis, Haramaya University, Haramaya, Ethiopia.

[7] Joao, C.M., Cerri, C.C., Lal, R., Dick, W.A., Piccolo, M.C., and Feig, B. E. 2009. Soil organic carbon and fertility interactions affected by a tillage chronosequence in a Brazilian Oxisol. Soil and Tillage Research, 104: 56 - 64.

[8] Singh, H., Sharma, K.N. and Arora, B.S. 1995. Influence of continuous fertilization to a maize system on the changes in soil fertility. Fertility Research, 40: 7 -19.

[9] Saikhe, H., Varadachari, C. and Ghosh, K. 1998a. Changes in carbon, nitrogen and phosphorus levels due to deforestation and cultivation. A Case study in Simplipal National Park, India. Plant and Soil, 198: 137 - 145.

[10] He, Z.L., Alva, A.K., Calvert, D.V., Li, Y.C. and Banks, D.J. 1999. Effects of nitrogen fertilization of grapefruit trees on soil acidification and nutrient availability in Riviera fine sand. Plant and Soil, 206: 11 - 19.

[11] Aluko, A.P. and Fagbenro, J.A. 2000. The role of tree species and land use systems in organic matter and nutrient availability in degraded Ultisol of Onne, Southeastern Nigeria. Proc. Annual Conf. Soil Science Society of Nigeria, 3: $89-292$

[12] Akamigbo, F.R and Asadu, C.A. 2001. The influence of parent materials on the soils of Southeastern Nigeria. East African Agriculture and Forest Journal, 48: 81 - 91.

[13] IFPRI (International Food Policy Research Institute) 2010. Fertilizer and Soil Fertility Potential in Ethiopia, Constraints and Opportunities for Enhancing the System, Working Paper. pp. 2-3.

[14] Gebreyohannes G, 2001. Spatial Variability of Selected Soil Properties and Degree of Degradation of Soils in Betmera watershed, Northern highland of Ethiopia. MSc. 
Thesis Alemaya University, Alemaya, Ethiopia.

[15] Wakene, N.C. 2001. Assessment of Important Physicochemical Properties of Nitosols under Different Management Systems in Bako area, Western Ethiopia, MSc.Thesis, Alemay University, Alemaya, Ethiopia.

[16] Mamo, Y. 2011. Influence of Land Use Systems on Selected Soil Physical and Chemical Properties at Agedit Watershed, South Gondar Zone, Amhara Regional State, MSc thesis, Haramaya University, Haramaya, Ethiopia

[17] Matersha, S.A and Mkhabela, T.S. 2001. Influence of land use on properties of ferralitic soil under low external input farming in Swaziland. Soil and Tillage Research, 62: 15 25 .

[18] Reynolds, W.D., Drury, C.F., Fox, C.A. and Zhang, T.Q. 2007. Land management effects on the near-surface physical quality of a clay loam soil. Soil and Tillage Research, 96: 316 - 330.

[19] Iris, V., Rogasik, J., Funder, U., Panten, K. and Schnug, E. 2009. Effect of tillage systems and P-fertilization on soil physical and chemical properties, crop yield and nutrient uptake. Soil and Tillage Research, 103: 137 - 143.

[20] Alexandra, M., Charles, R., Jeangros, B. and Sinaj, S. 2013. Effect of organic fertilizers and reduced-tillage on soil properties, crop nitrogen response and crop yield: Results of a 12-year experiment in Changins, Switzerland. Soil and Tillage Research, 126:11 - 18.

[21] Moscatelli, M.C, Di Tizio, A., Marinari, S. and Grego, S. 2007. Microbial indicators related to soil carbon in Mediterranean land use systems. Soil and Tillage Research, 97: $51-59$.

[22] Tiejun, Z., Wanga, Y., Wang, X., Wangc, Q. and Han, J. 2007. Organic carbon and nitrogen stocks in reed meadow soils converted to alfalfa fields. Soil and Tillage Research, 105: 143 - 148 .

[23] Xueli, D., Han, X., Liang, Y., Qiao, Y., Li, L. and Li, N. 2012. Changes in soil organic carbon pools after 10 years of continuous manuring combined with chemical fertilizer in a Mollisol in China. Soil and Tillage Research, 122: 36 41.

[24] Lemma, B., Berggren, D., Nilsson, I. and Olsson, M. 2006. Soil carbon sequestration under different exotic tree species in the southwestern highlands of Ethiopia. Geoderm, 136: 886 - 898 .

[25] Banafshe, K., Nili, N., Nourbakhsh , F., Sharifnabi, B. and Khademi, H. 2011. Does cultivation influence the content and pattern of soil proteins? Soil and Tillage Research, 111: 162 - 167.

[26] Balsa, M.E., Serrao, M.G., Martins, M.I.M., Castelo-Branco, M.A., Gusmao, M.R. and Fernandes, M.L. 1996. Effects of Pyrite Residue Amendment on Sulfur Availability in a Calcareous Soil Cropped with Sown Pasture in Fertilizers and Environment C. Rodriguez-Barrueco, editor. Kluwer academic Publ., Printed in the Netherlands. pp 453 - 455.

[27] Arshad, J., Moon, Y.S. and Abdin, M.Z. 2010. Sulfur -a general overview and interaction with nitrogen. Australian Journal of Crop Science, 4: 523 - 529.
[28] Joao, C.M., Cerri, C.C., Lal, R., Dick, W.A., Piccolo, M.C., and Feig, B. E. 2009. Soil organic carbon and fertility interactions affected by a tillage chronosequence in a Brazilian Oxisol. Soil and Tillage Research, 104: 56 - 64.

[29] Baker, M.R., Nys, C. and Picard, J.F. 1997. The effects of liming and gypsum application on a sessile oak (Quercus petraea) stand at Larcroix- Scaille (French Ardennes). I. Site characteristics, soil chemistry and aerial biomass. Plant and Soil, 150: 99 - 108.

[30] Adesodun, J.K., Adeyemi, E.F. and Oyegoke, C.O. 2007. Distribution of nutrient elements within water-stable aggregates of two tropical agro ecological soils under different land uses. Soil and Tillage Research, 92: 190 197.

[31] Tekalign M., Haque, I., and Kamara, C.S. 1988. Phosphorus Status of Ethiopian Vertisols: Management of Vertisols in Sub-Saharan Africa. Proceeding of the Conference Held at International Livestock Centre for Africa (ILCA), 31 August-4 September 1987.

[32] Belay, S. 2003. Integrated watershed management approach to sustainable land management (Experience of SARDP in East Gojjam and South Wollo). In: Tilahun Amede (Ed.). In: Proceedings of the Conference on the Natural Resource Degradation and Environmental Concerns in the Amhara National Regional State: Impact of Food Security, July 24 - 26, 2002, Bahir Dar. The Ethiopian Society of Soil Science. Addis Ababa, Ethiopia. pp.127-136.

[33] Barry, P. and Ejigu, J. 2005. Soil Fertility Practices in Wolaita Zone, Southern Ethiopia: Learning from Farmers, Policy and Research Series. FARM-Africa, 9-10, Southampton Place. pp. 1-27.

[34] Tegenu, A.E., Kassahun H.T., Collick, A.S., Adissu, T., Ashagrie, B.B., Tessema, Z.K., Derebe A., Solomon, D. and Steenhus, T.S. 2008. Soil Properties and Fertility Status Dynamics of Northwestern Ethiopia Influenced by Land Use Changes: Case of Dibanke Watershed. pp.1-13.

[35] Lalisa, A.D., Hager, H. and M. Sieghardt, 2010. Effects of Land Use Types on Soil Chemical Properties in Smallholder Farmers of Central Highland Ethiopia. Ekológia (Bratislava), 29(1):1 - 14.

[36] Taye, B. and Yifru, A. 2010. Assessment of Soil Fertility Status with Depth in Wheat Growing Highlands of Southeast Ethiopia. World Journal of Agricultural Science, 6(5): 525 - 531.

[37] Randall, J.S. and Anderson, S. 2005. Soils Genesis and Geomorphology, Cambridge University Press, United Kingdom.

[38] Jagdish, P. 2009. Soil of Nabibagh farm: Their characteristics and capability. The Geogra Revolulutionary India, 20:294-300.

[39] Chorowicz, J., Collet, B., Bonavia, F.F., Mohr, P., Parriot, J.F. and Kome, T. 1998. The Tana basin, Ethiopia: intra-plateau uplift, rifting and subsidence, Elsevier, 295:351-367.

[40] FAO (Food and Agriculture Organization) 2006. World reference base for soil resources: A framework for international classification, correlation and communication. 
$2^{\text {nd }}$ Edition, World Soil Resources Reports No. 103. FAO, Rome. pp. 67-101.

[41] Chilga District Agriculture and Rural Development Office, 2012

[42] Day, P.R. 1965. Particle fraction and particle size analysis. In: Black CA et al. (Eds). Methods of Soil Analysis. Part 2. American Society of Agronomy. pp.545 - 567.

[43] Rowell, D.L. 1997. Soil Science: Method and Application. Addison Wesley Longman Group UK, Singapore.

[44] Barauah, T.C. and Barthakulh, H.P. 1997. A Text Book of Soil Analysis. Vikas Publishing House, New Delhi, India.

[45] Chopra, S.H. and Kanwar, J.S. 1976. Analytical Agricultural Chemistry. Kalyani Publisher Ludhiana, New Delhi, India.

[46] Jackson, M.L. 1958. Soil Chemical Analysis. Prenstice-Hall, Inc., Engle Wood Cliffs. New Jersey. pp. $183-204$

[47] Bray, H.R. and Kurtz, L.T. 1945. Determination of organic and available forms of phosphorus in soils. Soil Science, 9: 39 - 46

[48] Chapman, H. D. 1965. Cation exchange capacity. In: C. A. Black, L. E. Ensminger and F. E. Clark (Eds). Methods of soil analysis. Agronomy. Inc., Madison, Wisconsin. American Society of Agronomy, 9: 891 - 901.

[49] Rowell, D.L. 1994. Soil Science: Methods and Applications. Addison Wesley Longman Limited. England. 350p.

[50] Walkley, A. and Black, C.A. 1934. An examination of different methods for determining soil organic matter and the proposed modification by the chromic acid titration method. Soil Science, 37: 29 - 38.

[51] Kowalenko, C.G. 1985. A modified apparatus for quick and versatile sulfate sulfur analysis using hydriodic acid reduction. Communication in Soil Science and Plant Analysis, 4(2):125-138.

[52] Sahlemedhin, S. and Taye, B. 2000. Procedure for Soil and Plant Analysis. National Soil Research Centre, Ethiopian Agricultural Research Organization, Addis Ababa, Ethiopia. 110p.

[53] Eyayu, M., Heluf, G., Tekalign, M. and Mohammed, A. 2009. Effects of land use change on selected soil properties in the Tera Gedam Catchment and adjacent agro-ecosystems, north-west Ethiopia. Ethiopian Journal of Natural Resources, 11: 35 - 62.

[54] Buurman, P. 1990. Soil catenas of Sumatran landscapes. Soil Data Base Management Project, Miscellaneous Papers No. 13: 97-109.

[55] Puget, P. and Lal, R. 2005. Soil organic carbon and nitrogen in a Mollisol in central Ohio as affected by tillage and land use. Soil and Tillage Research, 80: 201 - 213.

[56] Pam, H. and Brian, M. 2007. Interpreting Soil Test Results, What Do All the Numbers Mean? $2^{\text {nd }}$ Edition. NSW Department of Natural Resources. pp.1-152.

[57] Jones, C.A. 1983. Effect of soil texture on critical bulk densities for root growth. Soil Science Society of America
Journal, 47:1028-1211.

[58] Heluf, G., 2002. Soil and Water Management Research Program Summary Report of 2000/2001 Research Activities. Alemaya Research Center, Alemaya University. Ethiopia. 95p.

[59] Malo, D.D., Schumacher, T.E. and Doolittle, J.J. 2005. Long-term cultivation impacts on selected soil properties in the northern Great Plains. Soil and Tillage Research, 81: $277-291$.

[60] Cardelli, R., Marchini, F. and Saviozzi, A. 2012. Soil organic matter characteristics, biochemical activity and antioxidant capacity in Mediterranean land use systems. Soil and Tillage Research, 120: 8 - 14.

[61] Brady, N.C., and Weil, R.R. 2002. The Nature and Properties of Soils. 13th Edition. Prentice-Hall Inc., New Jersey; USA.

[62] Yimer, F., Ledin, S. and Abdulakdir, A. 2007. Changes in soil organic carbon and total nitrogen contents in three adjacent land use types in the Bale Mountains, southeastern highlands of Ethiopia. Forest Ecology Management, 242: 337 - 342.

[63] Tekalign, T. 1991. Soil, Plant, Water, Fertilizer, Animal Manure and Compost Analysis. Working Document No. 13. International Livestock Research Center for Africa, Addis Ababa. Tropial Agriculture, 68(1): 51-56.

[64] Wakene, N. and Heluf, G. 2003. Influence of land management on morphological, physical and chemical properties of some soils of Bako, Western Ethiopia. Agropedology, 13: 1 - 9.

[65] Diaz, R., M., Buenob, J., Gonza'lez-Prietoa, S.J. and Carballasa, T. 2005. Cultivation effects on biochemical properties, $\mathrm{C}$ storage and $15 \mathrm{~N}$ natural abundance in the $0-5$ $\mathrm{cm}$ layer of an acidic soil from temperate humid zone. Soil and Tillage Research, 84: 216 - 221.

[66] Guo, L.B. and Gifford, R.M. 2002. Soil carbon stocks and land use change: a met analysis. Global Change and Biology, 8: 345 - 360 .

[67] Tiwari, A., Dwivedi, A.K. and Dikshit, P.R. 2002. Longterm influence of organic and inorganic fertilization on soil fertility and productivity of soybean-wheat system in a Vertisols. Journal of Indian Society of Soil Science, 50: $472-475$.

[68] Charman, P.E.V., and Roper, M.M. 2007. Soil organic matter. In 'Soils - their properties and management'. 3rd Editionn. (Eds P. E. V. Charman and B. W. Murphy.), Oxford University Press: Melbourne. pp.276-285

[69] Urioste, A.M, Hevia, G. G., Hepper, E.N., Anton, L.E., Bono, A.A. and Buschiazzo, D.E. 2006. Cultivation effects on the distribution of organic carbon, total nitrogen and phosphorus in soils of the semiarid region of Argentinian Pampas. Geoderma, 136: 621 - 630.

[70] Havlin J.L, Beaton, J.D., Tisdale, S.L. and Nilson, W.L. 1999. Soil fertility and fertilizers: an introduction to nutrient management. $6^{\text {th }}$ Edition. Prentice Hall. Upper Saddle River, New Jersey. Jackson, M.L. 1958. Soil Chemical Analysis. Prentice Hall, Inc., Engle Wood Cliffs. New Jersey,USA. 
[71] Bruce, R. C., and Rayment, G. E. 1982. Analytical methods and interpretations used by the Agricultural Chemistry Branch for Soil and Land Use Surveys. Queensland Department of Primary Industries. Bulletin QB8 (2004), Indooroopilly, Queensland.

[72] Solomonm, D., Lehmann, J., Tekalign, M., Fritzsche, F. and Zech, W. 2001. Sulfur fractions in particle-size separates of the sub-humid Ethiopian highlands as influenced by land use changes. Geoderma, 102: 41- 59.

[73] Zhihui, Y., Singh, B.R. and Hansen, S. 2007. Aggregate associated carbon, nitrogen and sulfur and their ratios in long-term fertilized soils. Soil and Tillage Research, 95: $161-171$

[74] Nand, K.F., Baligar, V.C. and Jones, C.A. 2011. Growth and Mineral Nutrition of Field Crops. $3^{\text {rd }}$ Edition. Taylor and Francis Group, LLC, USA.

[75] Blair, G.J., Chinoim, N., Lefroy, R.D.B., Anderson, G.C. and Croccker, G.J. 1991. A soil sulfur test for pastures and crops. Australian Journal of Soil Resources, 29: 619 - 626.

[76] Muhammad. M.M., Nawaz, A.M., Fazal, C. and Shabab, U.D. 2001. Effects of gypsum as a sulphur fertilizer in cotton (Gossypium hirsutum L.) production. International Journal of Agriculture and Biology, 3(4): 375-377

[77] Allen V.B. and Pilbeam, D.J. 2007. Handbook of Plant Nutrition, Taylor and Francis Group.

[78] Reisenauer, H.M., Walsh, L.M. and Hoeft, R.G. 1973. Testing soils for sulfur, boron, molybdenum, and chlorine. In: Soil testing and plant analysis, L. M. Walsh and J. D. Beaton, Eds., Madison, WI: Soil Science Society of America. pp.173 - 200.

[79] EthioSIS (Ethiopia Soil Information System). 2014. Soil fertility status and fertilizer recommendation atlas for Tigray regional state, Ethiopia. July 2014, Addis Ababa, Ethiopia.

[80] [80] Probert, M.E. 1980. Sulfur in Australia, In: Freney JR, Nicholson AJ (eds), Australian Academy of Science, Canberra. pp.158 - 169.

[81] Ahmed, H. 2002. Assessment of Spatial Variability of Some Physicochemical Properties of Soils under Different Elevations and Land Use Systems in the Western Slopes of Mount Chilalo, Arsi. MSc Thesis, Alemaya University, Alemaya, Ethiopia.

[82] Bhat, J.A., Mandal, B., and Hazra, G.C., 2007. Basic slag as a liming material to ameliorate soil acidity in alfisols of sub-tropical India. American-Eurasian Journal of Agriculture and Environmental Science, 2: 321-327.

[83] Fageria, N. K., Santos, A. B. and Baligar, V. C. 1997a. Phosphorus soil test calibration for lowland rice on an Inceptisol. Agronomy Journal, 89:737 - 742.

[84] Shober, A.L. and Sims, J.T. 2003. Phosphorus restrictions for land application of biosolids: Current status and future trends. Journal of Environmental Quality, 32:1955-1964.

[85] Clements, B., and McGowen, I. 1994. Strategic fertilizer use on pastures. NSW Agriculture. Agnote Reg. 4/57, Orange, NSW.

[86] Henry, D.F. 1990. Fundamentals of Soil Science. Eighth
Edition. Michigan State University, John Wiley and Sons, New York. 360p.

[87] Gao, G., and Chang, C. 1996. Changes in cation exchange capacity and particle size distribution of soils associated with long-term annual applications of cattle feed lot manure. Soil Science, 161: 115 - 120.

[88] Saikhe, H., Varadachari, C. and Ghosh, K. 1998b. Effects of deforestation and cultivation on soil CEC and contents of exchangeable bases. A case study in Simplipal National Park, India. Plant and Soil, 204: 67 - 75.

[89] FAO (Food and Agriculture Organization) 2006. Plant Nutrition for Food Security: A Guide for Integrated Nutrient Management. FAO, Fertilizer and Plant Nutrition Bulletin No. 16, Rome.

[90] Eckert, D.J. 1987. Soil test interpretations. Basic cation saturation ratios and sufficiency levels. In 'Soil testing: Sampling, correlation, calibration and interpretations'. SSSA Special Publication No. 21. (Ed. J. R. Brown.), Soil Science Society of America: Madison, USA. pp.53 - 64.

[91] Barber, S. 1984. Soil Nutrient Bioavailability Mechanistic Approach. J. Wiley and Sons, Inc. New York, 398p

[92] Smaling, E.M.A., Nandwa, S.M. and Janssen, B.H. 1997. Soil Fertility in Africa is at Stake, In R.J. Buresh et al. (ed.) Replenishing Soil Fertility in Africa. SSSA Spec. Publ. 51. SSSA, Madison, WI. pp. 47-61.

[93] Foth, H.D. 1990. Fundamentals of Soil Science, 8th Edition. John Wiley and Sons, Inc., New York, USA.

[94] Hazelton, P. and Murphy, B. 2007. Interpreting soil test results: What do all the numbers mean? $2^{\text {nd }}$ Edition. CSIRO Publishing. 152p.

[95] Metson, A. J. 1961. Methods of chemical analysis for soil survey samples. Soil Bureau Bulletin No. 12, New Zealand Department of Scientific and Industrial Research, Government Printer: Wellington, New Zealand.

[96] Tilahun, T., Nigussie, D., Bayu, W. and Gebeyehu, S. 2013. Effect of farmyard manure and inorganic fertilizers on the growth, yield and moisture stress tolerance of rain-fed lowland rice. American Journal of Research Communication, 1(4): 275 - 301.

[97] Bharadwaj, V. and Omanwar, P.K. 1994. Long term effect of continuous rational cropping and fertilization on crop yields and soil properties. II. Effects on EC, pH, OM and available nutrients of soils. Journal of Indian Soil Sience Society, 42: 387-392.

[98] Sims, J.T. and Johnson. G.V. 1991. Micronutrient soil tests, in J.J. Mortvedt, Ed., Micronutrients in Agriculture, 2nd ed., SSSA Book Series Number 4, Soil Science Science of America, Madison, WI. pp.427 - 476. 